\title{
PENILAIAN KINERJA OBJEK WISATA TAMAN MARGASATWA MANGKANG BERDASARKAN PERSEPSI PENGUNJUNG
}

\author{
Performance Assessment of Mangkang Zoo Tourism Object \\ According to The Visitors Perception
}

Siti Handayani ${ }^{1}$, S. Sariffuddin ${ }^{1}$

\begin{abstract}
Abstrak: Taman Margasatwa Mangkang menjadi salah satu objek wisata andalan Kota Semarang yang dikembangkan dengan fungsi utama konservasi dan edukasi melalui atraksi penangkaran hewan, serta rekreasi sebagai fungsi pendukungnya. Permasalahan pada Taman Margasatwa Mangkang adalah pengembangan, pengelolaan, serta implementasi yang berpengaruh terhadap kinerjanya sehingga terjadi fluktuasi jumlah pengunjung setiap tahun. Penelitian ini bertujuan untuk menilai kinerja objek wisata Taman Margasatwa Mangkang berdasarkan persepsi pengunjung. Metode analisis yang digunakan dalam penelitian ini adalah metode kuantitatif, menggunakan metode accidental sampling dengan jumlah sampel 100 responden. Perolehan data akan dianalisis menggunakan statistik deskriptif, IPA, Gap, dan CSI. Penilaian kinerja Taman Margasatwa Mangkang berada pada kriteria baik dengan nilai kepuasan pengunjung secara keseluruhan 0,66 atau pada kriteria puas, namun kriteria ini kurang sesuai apabila dilihat dari hasil penilaian kinerja dan kepuasan pengunjung terhadap variasi dan kelengkapan hewan, dimana sebagian besar pengunjung merasa tidak puas terhadap atraksi penangkaran hewan yang memiliki kinerja buruk. Sehingga sebagian besar pengunjung lebih cenderung memanfaatkan kunjunganya untuk rekreasi karena permintaan terhadap atraksi utama belum dapat terpenuhi.
\end{abstract}

\section{Kata Kunci: Kinerja Pariwisata, Kepuasan Wisatawan, Penyediaan Pariwisata}

\begin{abstract}
Mangkang Zoo is one of main tourism object in Semarang developed with the primary functions of conservation and education through animal breeding attractions, and recreation as a supporting function. There are some problems of Mangkang Zoo on the development, management, and implementation that affect its performance and makes fluctuations number of visitors every year. This research aims to assess the performance of Mangkang Zoo tourism object according to the visitor's perception. The analytical method used in this study is a quantitative method and using accidental sampling with a sample of 100 respondents. Collecting data will be analyzed using descriptive statistical, IPA, Gap, and CSI. The performance assessment of Mangkang Zoo has good criteria with overall satisfaction value 0.66 or satisfied criteria, but the criteria are not exactly can be seen from the result of the performance assessment towards the variation and completeness of animals because most visitors are dissatisfied with the attractions of breeding animals that have poor performance. So most visitors prefer using visits to recreation because demand for the main attractions not be fulfilled.
\end{abstract}

Keywords: Tourism Performance, Tourist Satisfaction, Tourism Supply

\footnotetext{
${ }^{1}$ Departemen Perencanaan Wilayah dan Kota, Fakultas Teknik - Universitas Diponegoro
}

Korespondensi: siti.handayani15@pwk.undip.ac.id 


\section{PENDAHULUAN}

Artikel ini membahas mengenai penilaian kinerja objek wisata Taman Margasatwa Mangkang dengan melihat persepsi pengunjung terhadap penyediaan (supply) pariwisata yang ada di Taman Margasatwa Mangkang yaitu atraksi, pelayanan, transportasi, dan promosi. Taman Margasatwa Mangkang menjadi salah satu program unggulan pengembangan destinasi pariwisata Kota Semarang, sehingga Taman Margasatwa Mangkang dikembangkan menjadi kebun binatang untuk melayani pengunjung dari bagian utara Jawa Tengah, dengan basis utama warga Kota Semarang, karena di wilayah utara Jawa Tengah belum terdapat kebun bintang. Taman Margasatwa Mangkang memiliki fungsi utama sebagai konservasi dan edukasi, serta rekreasi sebagai fungsi pendukungnya. Untuk mendukung konsep tersebut pengelola Taman Margasatwa Mangkang menyediakan berbagai macam atraksi antara lain penangkaran hewan dan permainan anak, selain itu juga disediakan pelayanan/fasilitas, promosi, serta transportasi untuk mendukung kegiatan atraksi yang ada.

Penelitian ini bermula dari penelitian yang telah dilakukan oleh Pradana, dkk. (2013), Praniti, dkk. (2015), Santiko, dkk. (2013), Saputro, dkk. (2014), dan Pramudita, dkk. (2013) yang menyebutkan adanya masalah pengembangan, pengelolaan, serta implementasi pembangunan di Taman Margasatwa Mangkang yang terdiri dari masalah internal maupun masalah eksternal, hal ini yang menyebabkan terjadi fluktuasi jumlah pengunjung yang dipengaruhi oleh persepsi pengunjung terhadap objek wisata Taman Margasatwa Mangkang. Menurut Lee (2015) dalam penelitian kebun binatang di Korea, membuktikan bahwa lingkungan kebun binatang mempengaruhi persepsi pengunjung karena motivasi utama untuk kunjungan kebun binatang adalah rekreasi keluarga dan melihat berbagai macam hewan.

Penilaian terhadap kinerja objek wisata Taman Margasatwa Mangkang yang melibatkan pengunjung sebagai pelaku utama pariwisata dianggap penting karena persepsi positif pengunjung dapat berpengaruh terhadap pengembangan pariwisata, sesuai dengan yang telah dijelaskan oleh Lickorish, dkk. (1991) bahwa persepsi positif wisatawan tentang daerah tujuan wisata diperlukan dalam pengembangan pariwisata. Semakin tinggi persepsi wisatwan terhadap kinerja atribut di daerah tujuan wisata semakin tinggi juga kepuasan yang didapatkan (Ragavan, dkk., 2014). Persepsi wisatawan dipengaruhi oleh tingkat kepentingan, tingkat kepuasan dan penilaian terhadap produk pariwisata (Rangkuti, 2002).

Melihat begitu pentingnya peran kepuasan pengunjung terhadap kinerja objek wisata Taman Margasatwa Mangkang, maka perlu adanya upaya penilaian terhadap penyediaan (supply) pariwisata yang ada di Taman Margasatwa Mangkang. Oleh karena itu, penelitian ini menyajikan : (1) sejarah karakteristik pengunjung Taman Margasatwa Mangkang, (2) kondisi penyediaan (supply) pariwisata Taman Margasatwa Mangkang, (3) kinerja objek wisata Taman Margasatwa Mangkang berdasarkan persepsi pengunjung.

\section{METODE PENELITIAN}

Penelitian ini berupa penilaian terhadap kinerja objek wisata Taman Margasatwa Mangkang berdasarkan persepsi pengunjung. Konsep penilaian kinerja dalam penelitian ini merujuk pada merujuk pada pernyataan White (2010) menyebutkan bahwa terdapat empat indikator kunci keberhasilan kinerja pariwisata antara lain meningkatnya perekonomian, kepuasan wisatawan, kualitas lingkungan, serta kesejahteraan masyarakat. Penelitian ini memfokuskan pada indikator kepuasan pengunjung yang merupakan bagian dari persepsi positif terhadap objek wisata Taman Margasatwa Mangkang. Untuk mencapai tujuan penelitian ini, maka digunakan pendekatan kuantitatif melalui metode statistik deskriptif. Tiga sumber data digunakan di dalam penelitian ini yaitu kuesioner dengan target responden pengunjung Taman Margasatwa Mangkang, observasi lapangan, wawancara terstruktur 
dengan target informan kepala Taman Margasatwa Mangkang, dan data sekunder berupa laporan dan kebijakan-kebijakan pemerintah terkait dengan pariwisata khususnya Taman margasatwa Mangkang. Teknik pengambilan sampel yang digunakan adalah metode accidental sampling dengan tingkat kepercayaan yang digunakan adalah $90 \%$ dan kesalahan maksimum sebesar $10 \%$. Jumlah sampel yang digunakan adalah 100 responden pengunjung Taman Margasatwa Mangkang yang dibagi kedalam 2 kategori yaitu hari kerja dan hari libur. menurut Bapak Bambang selaku pengelola Taman Margasatwa Mangkang perbandingan jumlah pengunjung pada hari kerja dan hari libur adalah 1:9. Berikut merupakan distribusi pembagian sampel:

Tabel 1. Tabel Distribusi Pembagian Sampel

\begin{tabular}{|l|l|}
\hline \multicolumn{1}{|c|}{ Hari } & Jumlah Sampel \\
\hline Hari kerja & \\
\hline Hari Libur & 10 \\
\hline
\end{tabular}

Sumber: Hasil Analisis, 2015

Perolehan data baik data primer maupun sekunder yang diolah nantinya akan dianalisis menggunakan analisis IPA (Importance Performance Analysis), Gap, dan CSI (Customer satisfaction index) sebagai metode evaluatif menggunakan alat bantu skala likert 1 - 5 , dimanai nilai 5 untuk kondisi sangat puas/sangat penting dan nilai 1 untuk kondisi sangat tidak puas/ sangat tidak penting.

\section{PEMBAHASAN}

Secara geografis, Taman Margasatwa Mangkang terletak di Kelurahan Wonosari, Kecamatan Ngaliyan. Terdapat masalah pengembangan, pengelolaan, serta implementasi pembangunan yang menyebabkan terjadi fluktuasi jumlah pengunjung. Namun evaluasi terhadap kinerja Taman Margasatwa Mangkang baru dilakukan pada managemen pengelolaanya saja. Penilaian kinerja dalam penelitian ini dilakukan dengan melihat persepsi pengunjung terhadap penyediaan (supply) pariwisata yang ada di Taman Margasatwa Mangkang yaitu atraksi, pelayanan, transportasi, dan promosi.

\section{Analisis Karakteristik Pengunjung Taman Margasatwa Mangkang}

a. Karakteristik sosio-demografis

Karakteristik geografis dilihat berdasarkan jenis kelamin, umur, pendidikan terakhir, pekerjaan, pendapatan, tipe kunjungan, moda yang digunakan, lama kunjungan, dan daya beli. Berdasarkan hasil analisis karakteristik sosio-demografis diketahui bahwa Pengunjung Taman Margasatwa Mangkang sebagian besar merupakan pengunjung perempuan usia produktif (15-64 Tahun) dan disertai dengan anak-anak. Pengunjung memiliki tingkat pendidikan yang beragam, dengan sebagian besar pengunjung merupakan ibu rumah tangga yang dengan tingkat pendidikan tertinggi SMA. Pendapatan rata-rata pengunjung Taman Margasatwa Mangkang sebagian besar berkisar antara Rp 1.000.000,00 - Rp 1.500.000,00. Pada hari-hari kerja dan hari sabtu, pengunjung didominasi oleh rombongan sekolah dengan menggunakan moda transportasi bus pariwisata. Karena sebagian besar pengunjung merupakan rombongan sekolah, lama waktu berkunjung dibatasi sesuai dengan kebijakan masing-masing rombongan, dimana lama waktu kunjungan rata-rata 3-4 jam, berbeda dengan keluarga yang memiliki waktu kunjungan lebih fleksibel. Biaya rata-rata biaya dikeluarkan oleh pengunjung selama berada di kebun bintang adalah berkisar Rp 50.000 Rp 100.000 menurut pengunjung biaya ini dianggap masih terjangkau. Namun, tipe kunjungan kurang sesuai dengan motivasi utama kunjungan kebun binatang, karena 
sebagian besar pengunjung kebun binatang merupakan rombongan sekolah, sedangkan kunjungan yang didominasi oleh kunjungan keluarga hanya terjadi pada hari-hari tertentu seperti hari minggu hari libur lebaran, natal, dan tahun baru.

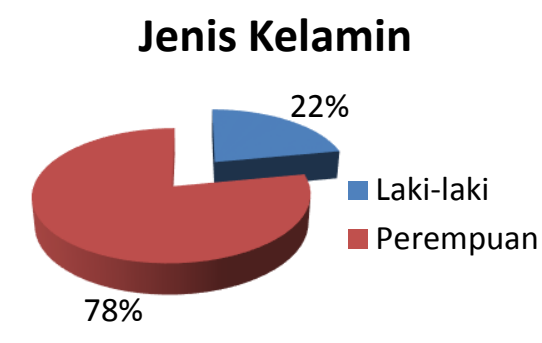

\section{Pendidikan Terakhir}
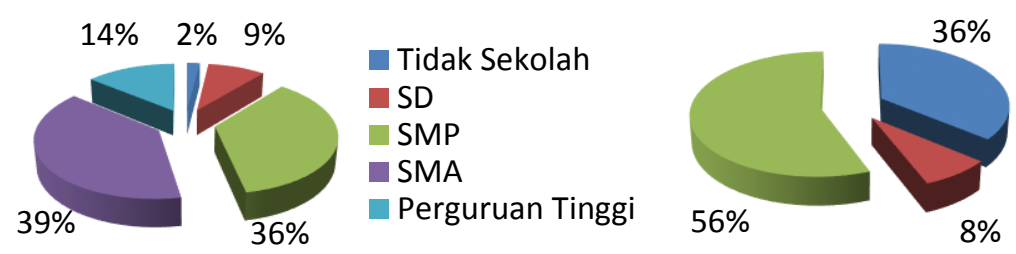

Keluarga/Saudara
Teman
Rombongan Sekolah

\section{Lama Kunjungan}
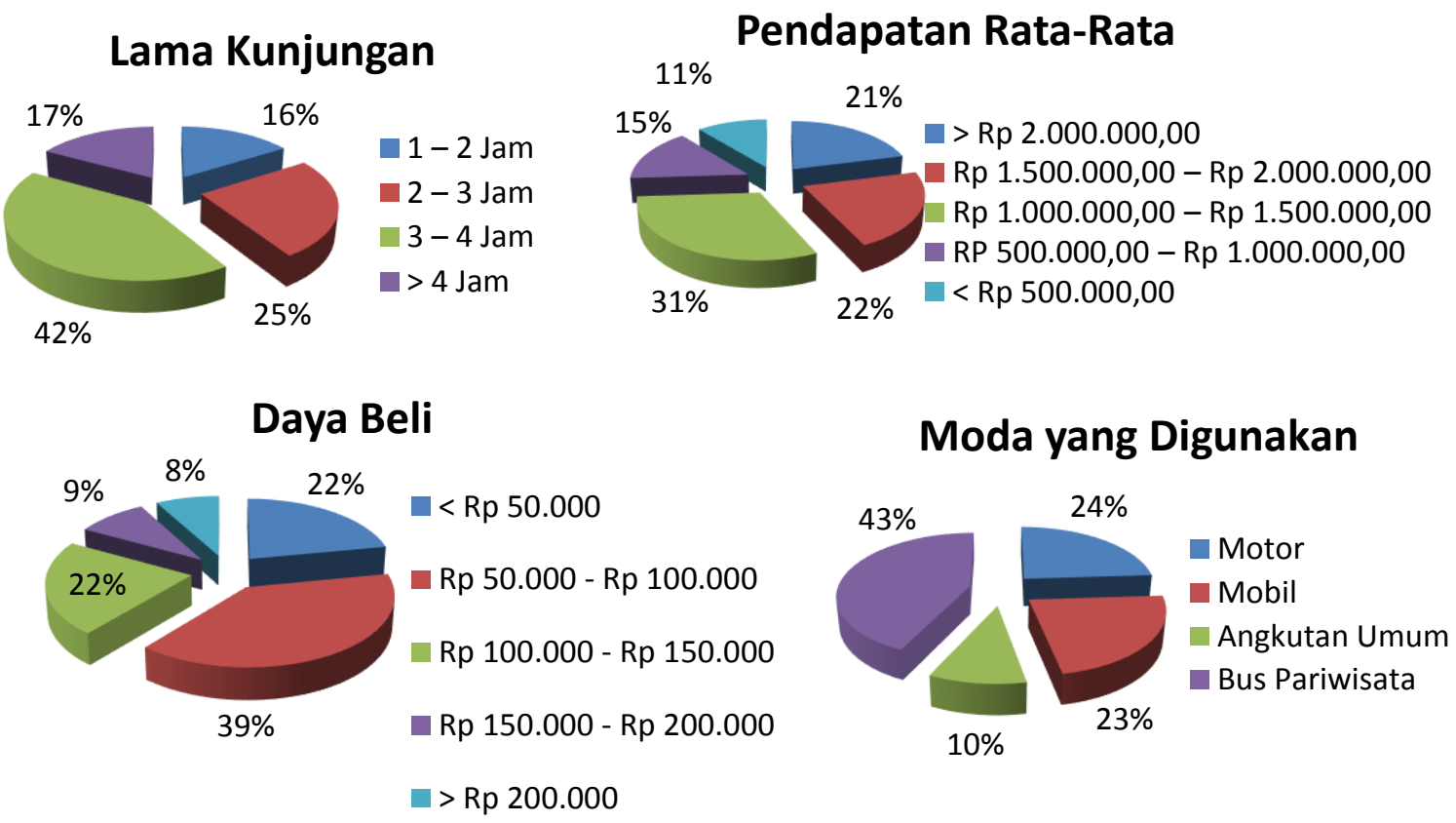

Sumber. Hasil Analisis, 2015

\section{Gambar 1. Karakteristik Sosio-demografis}

b. Karakteristik geografis

Karakteristik geografis dalam penelitian ini dapat dilihat berdasarkan asal pengunjung Taman Margasatwa Mangkang. Dari diagram diatas dapat diketahui bahwa Taman Margasatwa Mangkang memiliki jangkauan skala regional yaitu daerah-daerah yang berada di Semarang dan sekitarnya, karena Taman Margasatwa Mangkang tidak hanya berasal dari masyarakat lokal daerah Semarang saja, tetapi juga dari daerah sekitarnya. 


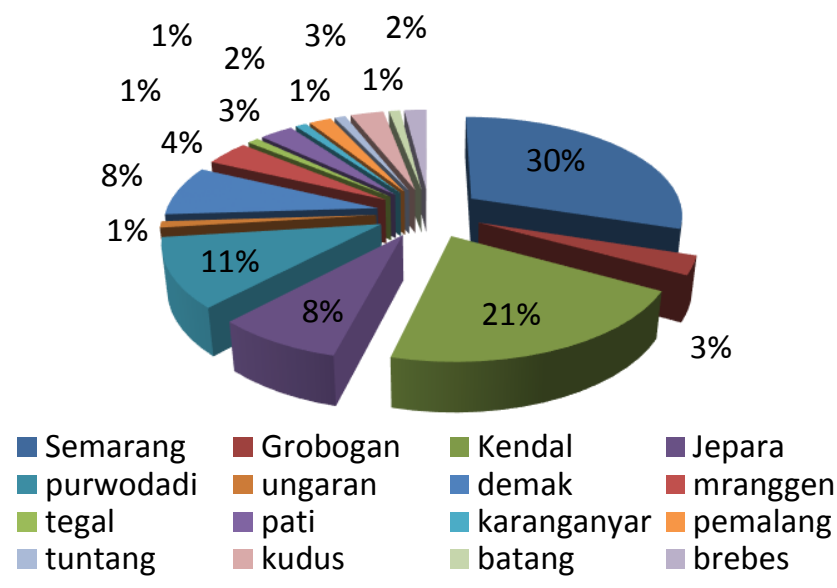

Sumber: Hasil Analisis, 2015

Gambar 2. Karakteristik Geografis Berdasarkan Asal Pengunjung

c. Karakteristik psikografis

Karakteristik psikografis dalam penelitian ini dapat dilihat dilihat berdasarkan frekuensi kunjungi dan motivasi pengunjung.

\section{Frekuensi Kunjungan}

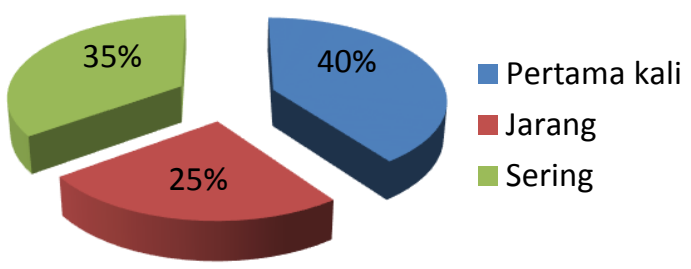

Motivasi Pengunjung

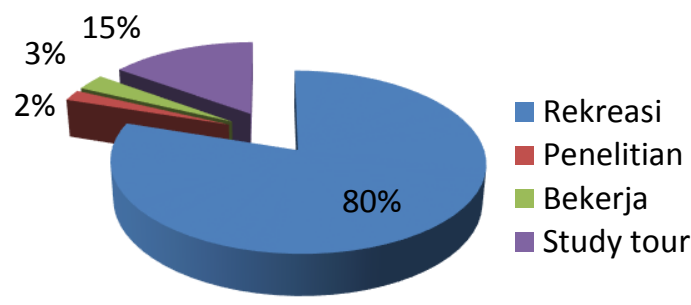

Sumber. Hasil Analisis, 2015

\section{Gambar 3. Karakteristik Psikografis}

Dari diagram diatas dapat diketahui bahwa sebagaian besar pengunjung baru pertama kali mengunjungi Taman Margasatwa Mangkang. Hal ini membuktikan bahwa Taman Margasatwa Mangkang mampu mempengaruhi motivasi pengunjung untuk mengunjungi Taman Margasatwa Mangkang, dimana sebagaian besar pengunjung memiliki motivasi untuk berekreasi, bentuk rekreasi yang dilakukan pengunjung Taman Margasatwa Mangkang, antara lain: bermain wahana permainan anak, sekedar menghabiskan waktu bersama rekan/keluarga, atau menikmati suasana yang ada. Dari diagram diatas dapat diketahui bahwa sebagaian besar pengunjung baru pertama kali mengunjungi Taman Margasatwa Mangkang. Hal ini membuktikan bahwa Taman Margasatwa Mangkang mampu mempengaruhi motivasi pengunjung untuk mengunjungi Taman Margasatwa Mangkang, dimana sebagaian besar pengunjung memiliki motivasi untuk berekreasi, bentuk rekreasi yang dilakukan pengunjung Taman Margasatwa Mangkang, antara lain: bermain wahana 
permainan anak, sekedar menghabiskan waktu bersama rekan/keluarga, atau menikmati suasana yang ada.

Karakteristik pengunjung digunakan sebagai bahan untuk melakukan evaluasi terhadap pengembangan objek wisata Taman Margasatwa Mangkang terutama pada penyediaan (supply) pariwisata yaitu atraksi, pelayanan, transportasi, dan promosi agar sesuai dengan permintaan pengunjung.

\section{Analisis Kondisi Penyediaan (Supp/y) Pariwisata di Taman Margasatwa Mangkang}

Komponen penyediaan (supply)terdiri dari atraksi, pelayanan/fasilitas, promosi, dan transportasi. Atraksi dibagi dalam 2 kelompok sesuai konsep Taman Margasatwa Mangkang yaitu konservasi dan edukasi, serta rekreasi.

a. Atraksi

Atraksi yang ada di Taman Margasatwa Mangkang dikelompokan berdasarkan fungsi Taman Margasatwa Mangkang ke dalam dua jenis atraksi yaitu konservasi dan edukasi, serta rekreasi. Konservasi dan edukasi bergabung menjadi satu yang terdapat pada atraksi penangkaran hewan. Pada atraksi penangkaran hewan dibagi kedalam 2 kelompok yaitu: hewan yang dikomersialkan dan hewan yang tidak dikomersialkan. Namun jumlah hewan sedikit dan tidak lengkap sehingga fungsi konservasi dan edukasi berjalan kurang maksimal.

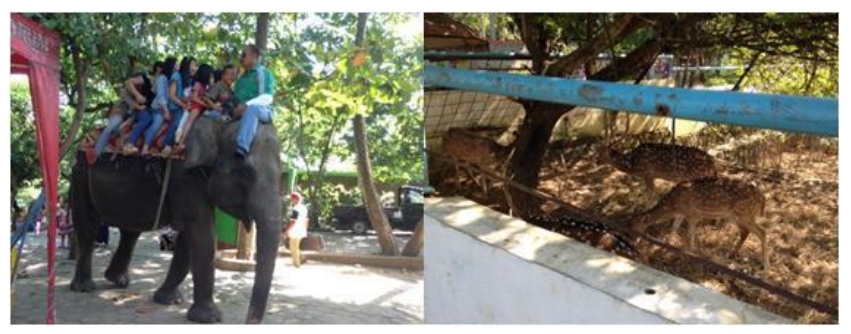

Sumber: Hasil Analisis, 2015

\section{Gambar 4. Penangkaran Hewan}

Sedangkan bentuk rekreasi yang terdapat pada Taman Margasatwa Mangkang antara lain: bermain wahana permainan anak, sekedar menghabiskan waktu bersama rekan/keluarga, atau menikmati suasana yang ada. Konsep rekreasi wahana bermain dibuat dengan menyediakan berbagai macam permainan anak.

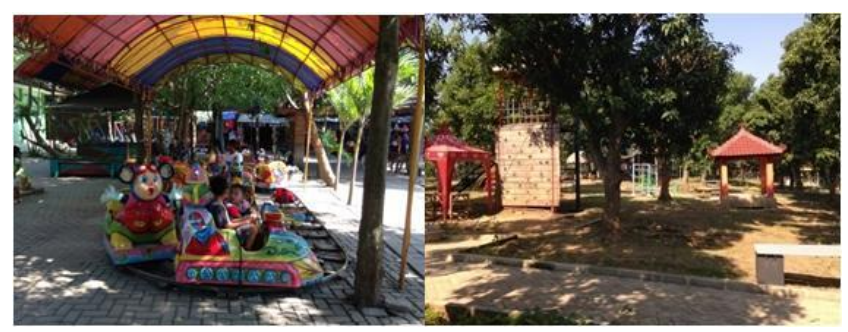

Sumber: Hasil Analisis, 2015

Gambar 5. Permainan Anak 
Atraksi permainan anak sudah sesuai dengan karakteristik pengunjung dan mampu memfasilitasi sebagian besar pengunjung yang di dominasi oleh anak-anak. Namun, terdapat beberapa kandang dan wahana permainan dengan kondisi yang kurang baik, berkarat, kotor,dan kurang terawat yang mempengaruhi persepsi negatif pengunjung. Karena fungsi konservasi dan edukasi tidak berjalan dengan maksimal sehingga fungsi rekreasi lebih dominan.

\section{b. Pelayanan/fasilitas}

Terdapat beberapa fasilitas yang sudah sesuai dengan permintaan pengunjung, fasilitas tersebut antara lain pasar, kantin, papan informasi, dan petunjuk arah. Namun, terdapat beberapa fasilitas yang belum sesuai baik dari sisi penyedia (supply) maupun dari sisi permintaan (demand).

Tabel 2. Kondisi Ketersediaan Fasilitas

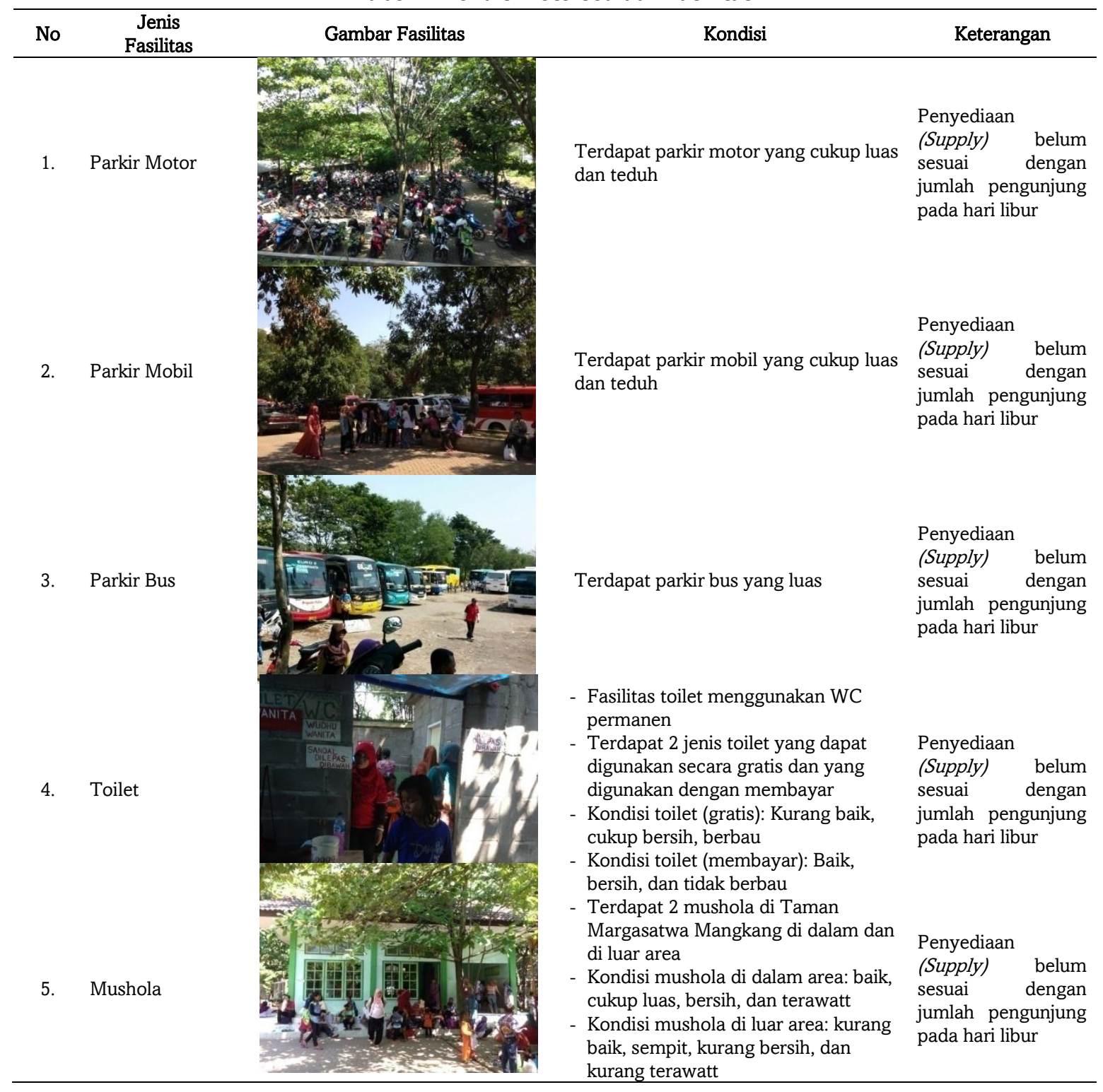




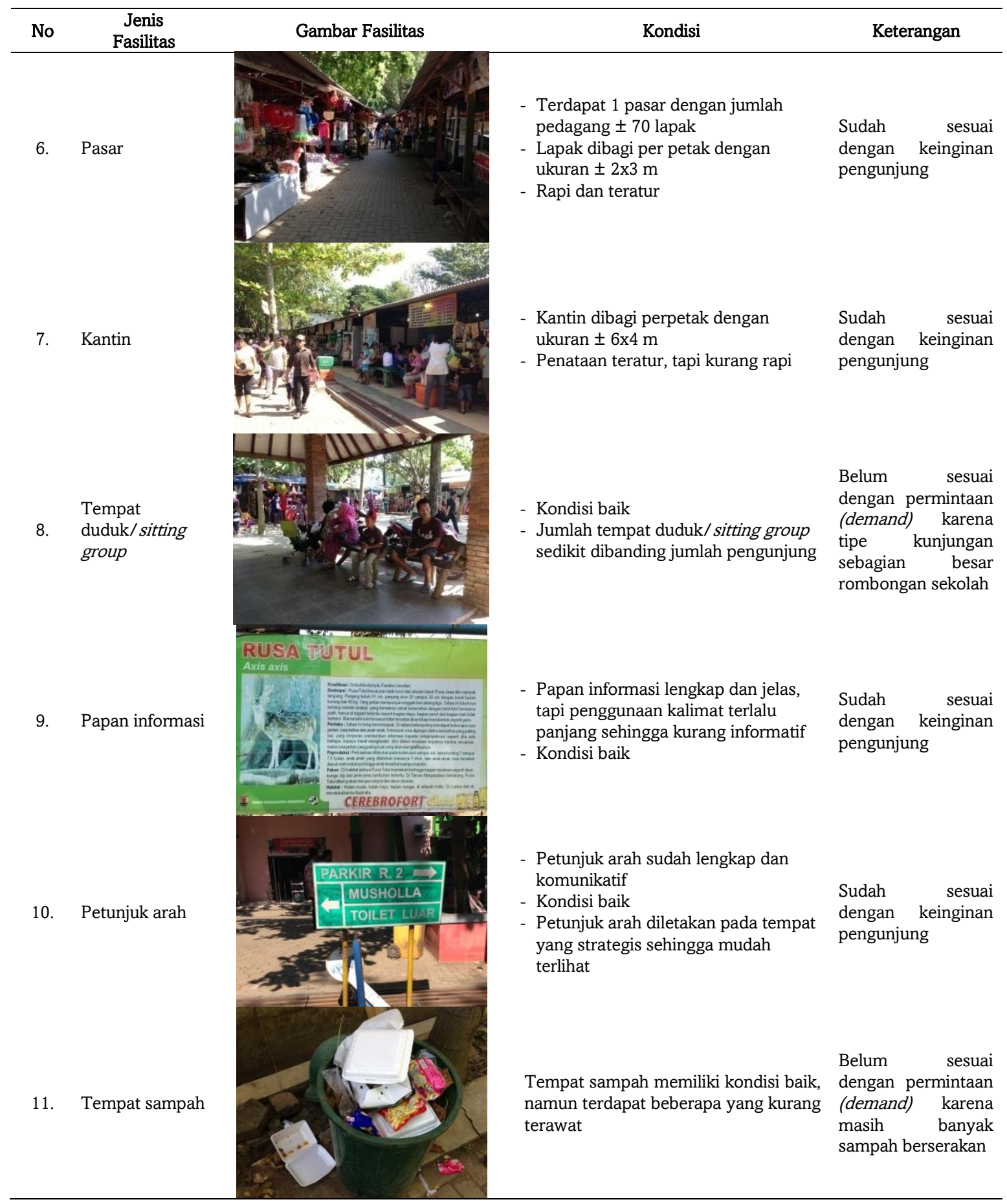

Sumber: Hasil Analisis, 2015

Dari sisi penyediaan (supply), fasilitas mushola, toilet, dan parkir dianggap belum sesuai karena karena belum mampu menfasilitasi peningkatan jumlah pengunjung pada hari libur tertentu. Sedangkan dari sisi pemintaan (demand), fasilitas tempat duduk/ sitting group dan tempat sampah kurang sesuai dengan karakteristik dan permintaan pengunjung, sehingga pengunjung memiliki persepsi negatif terhadap ketersediaan fasilitas tersebut. 


\section{c. Promosi}

Berbagai macam bentuk promosi telah dilakukan oleh pihak Taman Margasatwa Mangkang sebagai upaya untuk meningkatkan jumlah kunjungan. Salah satu upaya promosi yang dilakukan Taman Margasatwa Mangkang dengan menyelenggarakan acara/ event yang mendapatkan respon positif dari pengunjung.

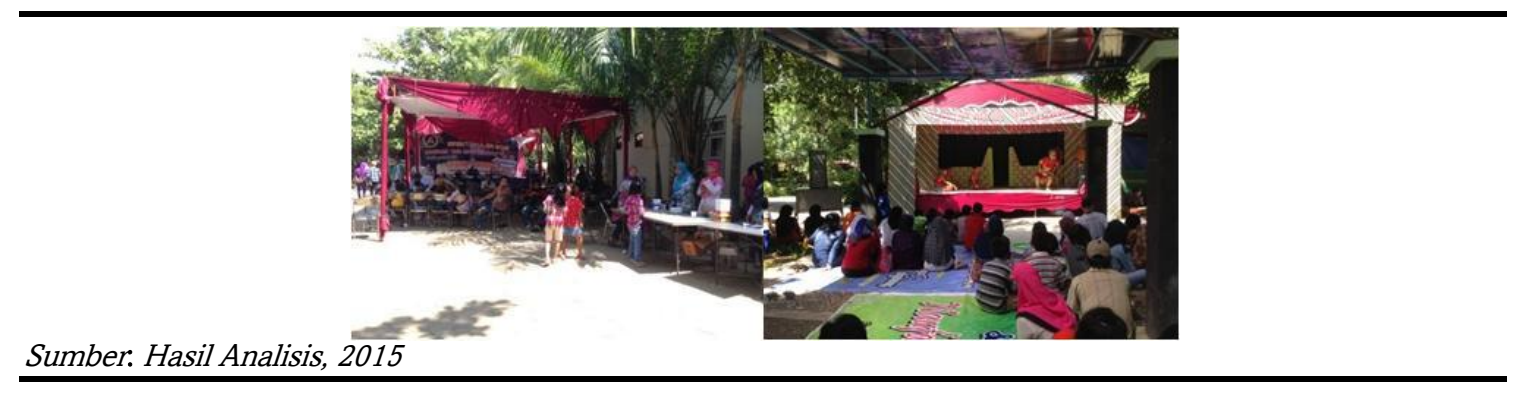

Gambar 6. Acara/ Event

Namun penyelenggaraan acara/ event tidak mempengaruhi minat wisatawan untuk berkunjung ke Taman Margasatwa Mangkang. Upaya promosi yang dianggap paling efektif menarik minat pengunjung untuk datang ke Taman Margasatwa Mangkang adalah promosi dari mulut ke mulut melalui perantara orang lain.

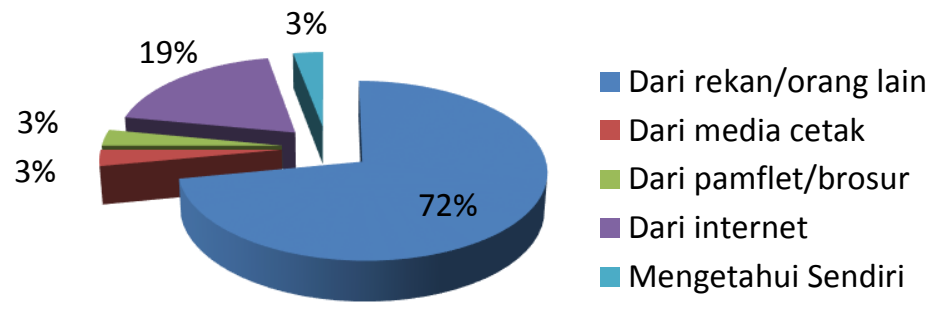

\section{Gambar 7. Informasi Promosi}

d. Transportasi

Taman Margasatwa Mangkang dapat dengan mudah diakses menggunakan kendaraan pribadi maupun angkutan umum.

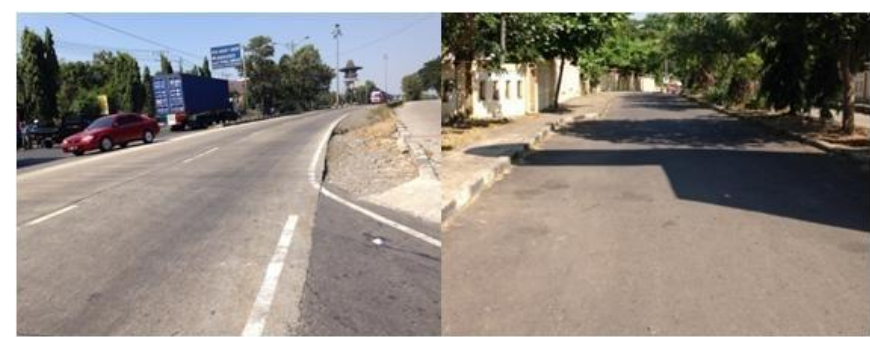

Sumber: Hasil Analisis, 2015

\section{Gambar 8. Kondisi Jalan}


Kondisi jalan untuk menuju Taman Margasatwa Mangkang saat ini dalam kondisi baik, sehingga mendukung akses menuju Taman Margasatwa Mangkang.

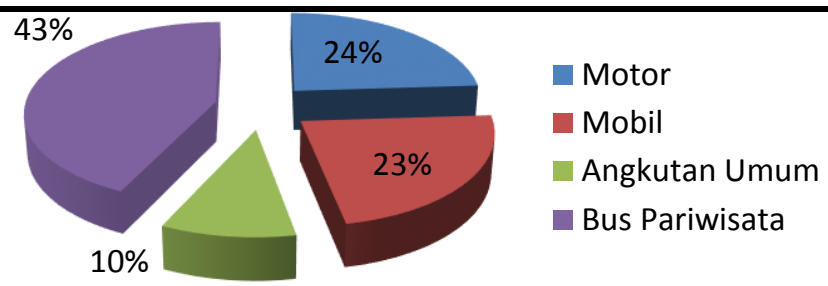

Sumber: Hasil Analisis, 2015

\section{Gambar 9. Moda yang digunakan}

Sebagian besar pengunjung Taman Margasatwa Mangkang memilih menggunakan bus pariwisata dan kendaraan pribadi daripada angkutan umum dengan alasan kenyamanan.

\section{Analisis Persepsi Terhadap Kondisi Penyediaan Pariwisata Berdasarkan Karakteristik Pengunjung}

Hasil analisis persepsi pengunjung diketahui tingkat kepentingan, tingkat kepuasan, dan nilai terhadap 17 atribut komponen penyediaan (supply).

a. Tingkat Kepentingan

Atribut yang memiliki indeks kepentingan tertinggi adalah kelengkapan dan variasi hewan dengan nilai rata-rata 4,56, dimana kelengkapan dan variasi hewan merupakan atribut yang dianggap paling penting karena Taman Margasatwa Mangkang memiliki fungsi utama korservasi dan edukasi, sehingga kebun binatang seharusnya memiliki koleksi satwa yang lengkap. Sedangkan atribut yang memiliki indeks kepentingan terendah adalah fasilitas pasar dengan nilai rata-rata 3,07.

\section{b. Tingkat Kepuasan}

Sebagian besar pengunjung merasa puas terhadap 11 atribut yaitu kelengkapan dan variasi permainan, kualitas pelayanan, biaya masuk, petunjuk arah, papan informasi,fasilitas pasar, fasilitas parkir, failitas toilet, fasilitas mushola, kantin, dan kemudahan akses. Tidak puas terhadap 4 atribut yaitu kelengkapan dan variasi hewan, kebersihan lingkungan, tempat duduk/rest area, dan fasilitas penunjang. Serta tidak tidak memberikan pendapat/netral terhadap 2 atribut yaitu acara/ event dan ketersediaan angkutan umum.

c. Nilai

- Analisis IPA (Importance Performance Analysis)

Berikut ini merupakan hasil analisis IPA yang disajikan ke dalam matriks IPA (Gambar 10). Kelengkapan dan variasi hewan sebagai fungsi utama Taman Margasatwa Mangkang yaitu konservasi dan edukasi berada pada skala prioritas utama yang harus ditingkatkan kinerjanya untuk peningkatan kepuasan pelayanan karena motivasi utama untuk kunjungan kebun binatang adalah rekreasi keluarga dan melihat berbagai macam hewan. 


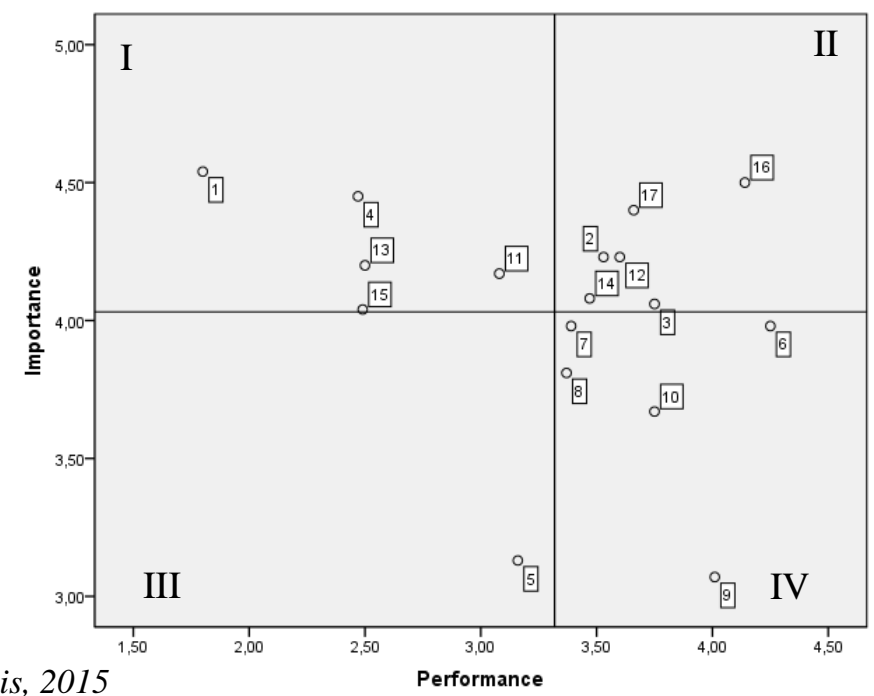

Sumber: Hasil Analisis, 2015

Gambar 10. Matriks IPA

Kuadran 1: Prioritas perbaikan

- Kelengkapan dan variasi hewan (1)

- Kebersihan lingkungan (4)

- Fasilitas toilet (11)

- Tempat duduk/rest area (13)

- Sarana penunjang (15)

Kuadran II: Pertahankan

- Kelengkapan dan variasi permainan (2)

- Kualitas pelayanan (2)

- Fasilitas mushola (12)

- Kantin (14)

- Kemudahan akses (16)

- Ketersediaan angkutan umum (17)

Kelengkapan dan variasi hewan sebagai fungsi utama Taman Margasatwa Mangkang yaitu konservasi dan edukasi berada pada skala prioritas utama yang harus ditingkatkan kinerjanya untuk peningkatan kepuasan pelayanan karena motivasi utama untuk kunjungan kebun binatang adalah rekreasi keluarga dan melihat berbagai macam hewan.

- Analisis Gap

Berikut ini merupakan tabel gap untukkualitas komponen penyediaan (supply) yang ada di Taman Margasatwa Mangkang:

Tabel 3. Kualitas Pelayanan

\begin{tabular}{llrrr}
\hline \multirow{2}{*}{ Variabel } & \multicolumn{1}{c}{ Atribut } & GAP & $\begin{array}{c}\text { GAP/ } \\
\text { Variabel }\end{array}$ & $\begin{array}{c}\text { Urutan Prioritas } \\
\text { Perbaikan }\end{array}$ \\
\hline \multirow{2}{*}{ Atraksi } & Kelengkapan dan variasi hewan & $-2,74$ & $-1,72$ & 1 \\
& Kelengkapan dan variasi permainan & $-0,7$ & & 7 \\
& Pelayanan & $-0,31$ & & 13 \\
& Kebersihan lingkungan & $-1,98$ & & 2 \\
& Sarana penunjang & Biaya masuk & $-1,55$ & \\
Pelayanan/f & Petunjuk arah & 0,27 & & 16 \\
asilitas & Papan informasi & $-0,59$ & $-0,63$ & 10 \\
& Fasilitas Pasar & $-0,44$ & & 11 \\
& Fasilitas parker & 0,94 & & 17 \\
& Fasilitas toilet & 0,08 & & 15 \\
& Fasilitas mushola & $-1,09$ & & 5 \\
\hline
\end{tabular}




\begin{tabular}{|c|c|c|c|c|}
\hline Variabel & Atribut & GAP & $\begin{array}{c}\text { GAP/ } \\
\text { Variabel } \\
\end{array}$ & $\begin{array}{c}\text { Urutan Prioritas } \\
\text { Perbaikan }\end{array}$ \\
\hline & Tempat duduk/Rest area & $-1,7$ & & 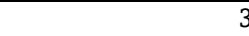 \\
\hline & Kantin & $-0,61$ & & 9 \\
\hline Promosi & Acara/event yang diadakan & 0,03 & 0,03 & 14 \\
\hline Transportasi & Kemudahan akses & $-0,36$ & $-0,55$ & 12 \\
\hline 11 Insportasi & Ketersediaan angkutan umum & $-0,74$ & $-0,05$ & 6 \\
\hline
\end{tabular}

Sumber: Hasil Analisis, 2015

Terdapat 13 atribut bernilai negatif dan 4 atribut yang bernilai positif, nilai negatif berarti nilai kinerja atribut berada di bawah tingkat kepentingan pengunjung atau dapat dikatakan kurang baik, sedangkan nilai positif berarti nilai kinerja atribut berada di atas tingkat kepentingan pengunjung atau dapat dikatakan baik. Urutan prioritas perbaikan ditentukan dari besar kecilnya nilai Gap, dimana semakin besar nilai Gap maka atribut tersebut semakin diprioritaskan untuk diperbaiki.

- Analisis CSI (Customer Satisfaction Index)

Berikut ini merupakan perhitungan kepuasan pengunjung secara keseluruhan dengan menggunakan rumus :

$$
\operatorname{CSI} \frac{\sum_{k=1}^{p} \mathrm{WS}_{\mathrm{k}}}{H S} \mathrm{x} 100 \%
$$

Karena skala maksimum yang digunakan adalah 5, maka:

$$
\text { CSI } \frac{3,32}{5} \times 100 \%=0,66 \text { atau } 66 \%
$$

Hasil analisis penilaian kepuasan pengunjung secara keseluruhan berada pada kriteria PUAS dengan nilai 0,66. Sehingga dapat diketahui bahwa secara keseluruhan kinerja Taman Margasatwa Mangkang berada pada kriteria BAIK, karena telah berhasil memberikan kepuasan terhadap pengunjungnya. Kepuasan akan sangat mempengaruhi niat untuk mengunjungi kembali dimasa yang akan datang yang ditunjukan oleh keinginan wisatawan untuk mengunjungi kembali Taman Margasatwa Mangkang.

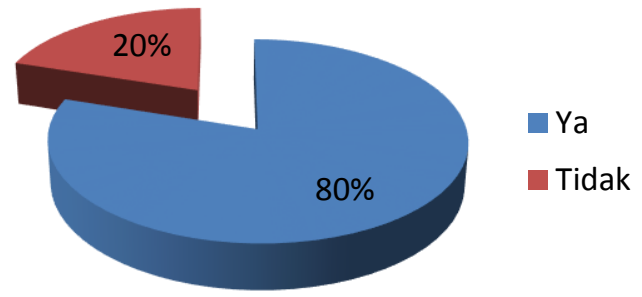

\section{Gambar 11. Keinginan Mengunjungi Kembali}

Dari diagram diatas dapat diketahui bahwa sebagian besar wisatawan memiliki keinginan untuk mengunjungi kembali Taman Margasatwa Mangkang dengan persentase sebesar $80 \%$ dengan motivasi untuk rekreasi. Hasil dari persentase keinginan untuk mengunjungi kembali Taman Margasatwa Mangkang sesuai dengan apa yang dikemukakan oleh Ragavan, dkk. (2014) dimana semakin tinggi persepsi wisatwan terhadap kinerja atribut di daerah tujuan wisata semakin tinggi juga kepuasan yang 
didapatkan, sehingga wisatawan memiliki keinginan untuk mengunjungi kembali objek wisata tersebut.

Taman Margasatwa Mangkang memiliki fungsi utama konservasi dan edukasi melalui atraksi penangkaran hewan, dan rekreasi sebagai fungsi pendukungnya. Selain itu Lee (2015) dalam penelitian kebun binatang di Korea, berpendapat bahwa salah satu motivasi utama untuk kunjungan kebun binatang adalah untuk melihat berbagai macam hewan. Namun, apabila dilihat dari fungsi utama dan motivasi utama kunjungan kebun binatang, kriteria baik pada penilaian kinerja objek wisata Taman Margasatwa Mangkang kurang sesuai dengan hasil penilaian kinerja dan kepuasan pengunjung terhadap variasi dan kelengkapan hewan. Dimana dari hasil analisis tingkat kepuasan pengunjung diketahui bahwa nilai kepuasan pengunjung terhadap kelengkapan dan variasi hewan memiliki nilai yang paling kecil yang berarti sebagian besar pengunjung merasa tidak puas karena atribut yang menjadi fungsi utama dari Taman Margasatwa Mangkang dan motivasi utama dalam kunjungan kebun binatang untuk melihat hewan tidak berjalan dengan baik. Selain itu, pada analisis IPA juga diketahui kelengkapan dan variasi hewan memiliki kinerja yang buruk, dimana pengunjung merasa tidak puas terhadap atraksi yang keberadaanya dianggap penting dalam atraksi kebun binatang. Dalam penelitian ini dapat diketahui bahwa atraksi penangkaran hewan tidak termasuk dalam penilaian baik kinerja objek wisata Taman Margasatwa Mangkang. Atraksi penangkaran hewan yang menjadi fungsi utama kebun binatang tidak berjalan dengan baik karena belum dapat memenuhi permintaan pengunjung sehingga sebagian besar pengunjung lebih memilih memanfaatkan kunjunganya untuk rekreasi. Kepuasan pengunjung selama melakukan kegiatan rekreasi juga dipengaruhi oleh pelayanan/fasilitas, promosi, dan transportasi yang ada di Taman Margasatwa Mangkang.

\section{KESIMPULAN}

Berdasarkan hasil penelitian yang telah dilakukan, dapat diketahui bahwa persepsi pengunjung dapat berpengaruh terhadap kinerja Taman Margasatwa Mangkang. Penilaian kinerja dari atraksi, pelayanan/fasilitas, transportasi, dan informasi promosi Taman Margasatwa Mangkang berdasarkan persepsi pengunjung berada pada kriteria baik dengan nilai kepuasan pengunjung secara keseluruhan 0,66 atau pada kriteria puas, namun kriteria ini tidak termasuk untuk kinerja atraksi penangkaran hewan karena memiliki kinerja yang buruk. Sehingga sebagian besar pengunjung merasa tidak puas dan lebih cenderung memanfaatkan kunjunganya untuk rekreasi karena permintaan terhadap atraksi utama belum dapat terpenuhi.

\section{DAFTAR PUSTAKA}

lee, H.-S. 2015. Measurement of visitors' satisfaction with public zoos in Korea using importance-performance analysis. Tourism Management. 47, 251-260.

Lickorish, L. J., Jefferson, A., Bodlender, J. \& Jenkins, C. L. 1991. Developing tourism destinations: policies and perspectives. Harlow, UK: Longman Group UK Limited.

Pradana, S. H., Larasati, E. \& Mustam, M. 2013. Strategi Pengembangan Ekowisata Taman Margasatwa Mangkang Kota Semarang. Journal of Public Policy and Management Review. 2, 491-500.

Pramudita, A., Lestari, H. \& Sulandari, S. 2013. Implementasi Pembangunan Kepariwisataan di Taman Margasatwa Mangkang Kota Semarang. Journal of Public Policy and Management Review. 2, 11-20.

Praniti, D. L., Widowati, N. \& Subowo, A. 2015. Strategi Pengembangan Pariwisata Kota Semarang (Studi Kasus Peningkatan Obyek Wisata Taman Margasatwa Semarang. Journal of Public Policy and Management Review. 4, 179-195.

Ragavan, N. A., Subramonian, H. \& Sharif, S. P. 2014. Tourists' perceptions of destination travel attributes: An application to International tourists to Kuala Lumpur. Procedia-Social and Behavioral Sciences. 144, 403411. 
Rangkuti, F. 2002. Measuring customer satisfaction: Teknik Mengukur dan Strategi Meningkatkan Kepuasan Pelanggan. Jakarta: PT Gramedia Pustaka Utama.

Santiko, L. I., Suwitri, S. \& Sulandari, S. 2013. Pengelolaan Obyek Wisata Taman Margasatwa Mangkang Kota Semarang. Journal of Public Policy and Management Review. 2, 174-183.

Saputro, W. E., Marom, A. \& Maesaroh, M. 2014. Strategi Pengelolaan Obyek Wisata Taman Margasatwa Semarang. Journal of Public Policy and Management Review. 3, 138-148.

White, S. 2010. Measuring Tourism Locally Guidance Note Four: Tourism Benchmarking and Performance Indicators. Tourism Intelligence Unit 1.0. 